\section{\#Sportsuisse2018 - 15-16 November 2018 - Come and get a taste for the Swiss way, and have a Muesli with us}

\author{
German Clénin, ${ }^{1,2}$ Boris Gojanovic ${ }^{2,3,4}$
}

Have you ever tasted our very special Swiss Muesli? ${ }^{1}$ The famous Swiss breakfast invented by Dr Bircher around 1900 has since crossed neighbouring borders and conquered the world, with each country adding their own ingredients to a very healthy original recipe. We love our muesli, but we also love to share with you a particular fondness for a sports medicine muesli of a different kind, the British Journal of Sports Medicine (BJSM).

$B J S M$ has nourished a community of sports medicine and physiotherapy societies, sharing the goodness, connecting people and stimulating thoughts. Just like the Swiss muesli, ${ }^{2}$ BJSM is perfect food for thought: you can enjoy it in paper sitting at your table, or can grab it as the perfect snack on-the-go, with its fantastic app and social media channels that keep you energised. Every member society adds to great content and contributes to make an impact in people's lives through better knowledge and behaviours with regards to physical and sporting activity, always putting health first. This spans from injuries in sports to non-communicable diseases, touching health and performance equally for all stakeholders. At least this is how we, the Swiss Sports Medicine Society, understand our role.

\section{INTERDISCIPLINARITY, A SWISS DNA}

Switzerland owes its remarkable stability to a tradition of working in complex multi-cultural, lingual and political environments. This is part of our DNA. We are proud of this diversity which stimulates and challenges us equally.

In our country, sports medicine is not a full specialty, but regroups medical practitioners from various specialties, like general

\footnotetext{
'Sportsmedicine Centre Bern-Ittigen, Bern, Switzerland ${ }^{2}$ Swiss Sports Medicine Society (SGSM/SSMS), Geneva, Switzerland

${ }^{3}$ Swiss Olympic Medical Center, Hôpital de La Tour, Geneva, Switzerland

${ }^{4}$ Interdisciplinary Center for Adolescent Sports Medicine, Woman-Mother-Child Department (DFME), Lausanne University and Hospital, Lausanne, Switzerland

Correspondence to Dr Boris Gojanovic, Sportsmedicine Centre Bern-Ittigen, Bern 3063, Switzerland; boris.gojanovic@latour.ch
}

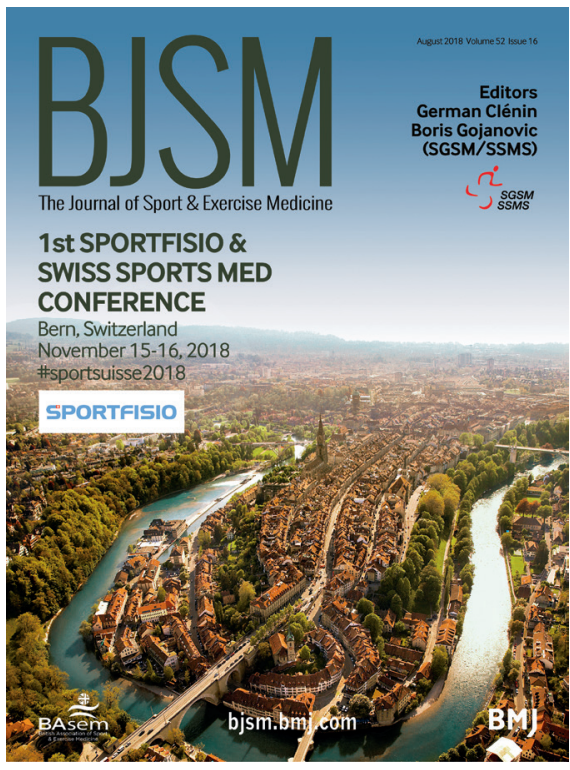

Figure 1 Join us at the Swiss Medicine Society (SSMS) and Swiss Sports Physiotherapy Association (SSPA, Sportfisio) in Bern on 15-16 November 2018.

medicine, orthopaedics, physical medicine, and cardiology. We find ways to work together, develop a common language, share goals and collaborations for patients and athletes.

Our trade requires multiple ingredients for the perfect 'sports medicine' muesli: physiotherapy, sports nutrition and psychology, exercise physiology, sport sciences, and more. Our closest siblings are the physiotherapists. We cannot treat athletes and patients without a strong network for rehabilitation and prevention.

\section{\#SPORTSUISSE2018}

With this in mind, we have decided to join our efforts and put together a stellar interdisciplinary conference in wonderful Swiss capital city of Bern (figure 1); we will welcome a broad panel of speakers to discuss everythinghip and groin, load monitoring and recovery.

Not only will you attend lectures by leading experts, but you will also get to explore the spirit and charm of Bern while strolling along the Aare or participating in the Wake-up-and-run event in the old medieval town, before grabbing your perfect breakfast... you know which one!

We are thankful for BJSM's support for the conference, and look forward to your presence.

\section{IN THIS SWISS SPORTS MEDICINE ISSUE}

We have chosen a fantastic mix of papers that span across the many topics cherished by our colleagues: in the editorial section, you will read about performance support teams (Sporer et al, see page 1014) and training load (see page 1016) topics. Also featured is a great piece by the legendary Roald Bahr on the importance of injury and illness burden, beyond their incidence (see page 1018).

In the articles section, Enda King et al (see page 1054) present telling findings from a rehabilitation programme for athletic groin pain, focusing on intersegmental muscular control in linear running and complex drills. Essentially, they present good results on HAGOS scores by choosing functional retraining classical anatomical-based rehabilitation. You will also read systematic reviews intervention for quality of life in knee osteoarthritis (Briani et al, see page 1031) or foot orthoses in heel pain (Rasenberg et al, see page 1040).

We thank the BJSM team for the opportunities to share some swissness, and we look forward to seeing you at \#sportsuisse2018.

Twitter German Clénin @DrAthletesHealth, Boris Gojanovic @DrSportSante, Swiss Sports Medicine Society@SwissSportsMed.

Competing interests None declared.

Patient consent Not required.

Provenance and peer review Commissioned; internally peer reviewed.

(C) Author(s) (or their employer(s)) 2018. No commercial re-use. See rights and permissions. Published by BMJ.

\section{Check for updates}

To cite Clénin G, Gojanovic B. Br J Sports Med 2018;52:1013

Br J Sports Med 2018;52:1013.

doi:10.1136/bjsports-2018-099627

\section{REFERENCES}

1 Clenin GE. Breakfast, a good start to the day - my kingdom for a Muesli in a Bowl. In: Athletes'health \& top performance: Inhouse Publishing, Underwood Brisbane, 2016:364-365.

2 Adolphus K, Lawton CL, Dye L. The effects of breakfast on behavior and academic performance in children and adolescents. Front Hum Neurosci 2013;7:425. 